\title{
Ağır amitriptilin zehirlenmesi ve plazmaferez
}

\section{Severe amitriptline intoxication and plasmapheresis}

\author{
Tülin Çataklı, Inci Arıkan, Bülent Alioğlu, Beray Selver, Yıldız Dallar \\ Sağlık Bakanlığı Ankara Eğitim ve Araştırma Hastanesi, Çocuk Sağı̆̆ı ve Hastalıkları Kliniği, Ankara, Türkiye
}

\section{Özet}

İlaçla zehirlenme nedeniyle acil servislere başvuran olgular içerisinde trisiklik antidepresan ilaçlar sık görülen ve yaşamı tehdit eden zehirlenme nedenlerindendir. Özellikle çocuklarda önemli hastalık ve ölüm nedeni olmaktadır . Dağılım hacimlerinin yüksek olması ve proteinlere yüksek oranda bağlanmaları nedeni ile zehirlenme bulguları erken ortaya çıkmaktadır. Plazmaferez aminotriptilin teofilin, diltizem, karbamezepin, L-tiroksin, verapamil, civa gibi ağır metal zehirlenmelerinde oldukça etkilidir. Amerikan Aferez Derneği, belirli ve geleneksel tedavilere cevap vermeyen ilaç zehirlenmelerinde birincil tedaviye destek olarak plazmaferez önermektedir. Bu yazıda, ağır amitriptilin zehirlenmesi ile başvuran iki olguda plazmaferez tedavisinin yüz güldürücü olduğu vurgulanmak istenmiştir. (Türk Ped Arş 2012; 47: 216-7)

Anahtar sözcükler: Amitriptilin, çocuk, plazmaferez, zehirlenme

\section{Summary}

Tricyclic antidepressant intoxication is one of the most frequently seen and life-threatening causes of intoxication among referrals to emergency departments because of drug intoxication. Especially in children, it is a major cause of mortality and morbidity. Intoxication symptoms are observed in the early phase because of a high volume of distribution and a high degree of plasma protein binding. Plasmapheresis is very effective in poisonings with amitriptyline, theophylline, diltiazem, carbamazepine, L-thyroxin, verapamil and heavy metals including mercury. American Apheresis Association Guide recommends plasmapheresis to support primary treatment in drug poisonings which do not respond to certain and traditional treatments. In this report, we wanted to emphasize that plasmapheresis treatment was successful in two subjects who presented with amitriptyline intoxication. (Turk Arch Ped 2012; 47: 216-7)

Key words: Amitriptyline, child, intoxication, plasmapheresis

\section{Giriş}

Amitriptilin yüksek etkinlikte ve ucuz olması nedeni ile trisiklik antidepresan olarak doktorlar tarafından sıkça reçetelenmekte, hastalar tarafından da kolaylıkla reçetesiz elde edilebilmektedir. Çocuklarda kaza ile ergenlerde özkıyım nedeniyle trisiklik antidepresan zehirlenmesi sık görülmektedir. Amitriptilinin etkilerinin doz bağımlı olarak ortaya çıkması ve plazma proteinlerine yüksek oranda bağlanması nedeniyle atılmasında hemodiyaliz ve hemoperfüzyon yeterli olamamaktadır $(1,2)$.

$\mathrm{Bu}$ yazıda amitriptilin zehirlenmesi nedeniyle plazmaferez yapılan iki olgu ile ilgili deneyimlerimiz sunulmuştur.

\section{Olgu 1}

Üç yaşında kız hasta ilaç zehirlemesi tanısıyla bir başka merkezden hastanemize sevk edildi. Hastanın sayısını tam olarak bilmedikleri (yaklaşık olarak 15-20 adet, 50 mg/kg) amitriptilin tabletlerini aldıktan sonra uyku halinin olması üzerine hastaneye götürüldüğü, midesinin yıkandığı, nöbetinin olması üzerine hastanemize sevk edildiği öğrenildi. Fizik incelemesinde genel durumu kötü, bilinci kapalı, pupilleri geniş, ışık refleksi zayıf olan hastanın, Glascow koma çizelgesi 4 olup, taşikardi (142/dak) ve hipotansiyonu (70/40 $\mathrm{mmHg}$ ) vardı. Elektrokardiyografide sinüs taşikardisi dışında sorun 
saptanmadı. Hastanın diğer fizik inceleme ve laboratuvar sonuçları normal sınırlardaydı. Amitiriptilin zehirlenmesi tanısı ile Yoğun Bakım Servisi'ne yatırılan hastaya damardan sıvı, bikarbonat, aktif kömür, lidokain ve antikonvülzan tedavi başlandı. Tedaviye rağmen konvülziyonları devam eden ve bilinci açılmayan hastanın aldığı ilaç dozu öldürücü dozun üzerinde olduğu için plazmaferezden faydalanabileceği düşünüldü. Hastaya femoral venöz kateter açılarak toplam plazma miktarının 1,5 katı kadar (yaklaşık $1000 \mathrm{~mL}$ ) taze donmuş plazma ile Fresenius Com. Tec marka cihaz ile plazma değişim işlemi yapıldı. İşlem sonrasında komplikasyon gözlenmedi. Plazma değişiminin bitiminden yaklaşık altı saat sonra hastanın bilinci açıldı, 48 saat gözlemden sonra klinik ve laboratuvar bulguları düzeldi.

\section{Olgu 2}

Dokuz yaşında kız hasta, ailesi tarafından bilinç kaybı yakınması ile hastanemiz Çocuk Kliniği Acil Polikliniği'ne getirildi. Öyküsünde annesinin migren tedavisi için kullandığı etken madde olarak amitriptilin içeren ilaçtan sayısını bilmedikleri miktarda içmiş olduğu öğrenildi. Fizik incelemesinde genel durumu kötü, bilinci kapalı, pupilleri geniş, ışık refleksi zayıf olan hastanın, Glascow koma çizelgesi 5 olup, taşikardisi (156/dak) vardı. Elektrokardiyografide sinüs taşikardisi dışında patoloji saptanmadı. Hastanın diğer fizik inceleme ve laboratuvar sonuçları normaldi. Amitiriptilin zehirlenmesi tanısı ile Yoğun Bakım Servisi'ne yatırılan hastaya damardan sıvı, bikarbonat, aktif kömür ve lidokain başlandı. Tedaviye rağmen bilinci açılmayan hastanın aldığı ilaç dozu ölümcül dozun üzerinde olduğu için plazmaferezden faydalanabileceği düşünüldü. Hastaya femoral venöz kateter yerleştirilerek toplam plazma miktarının 1-1,5 katı kadar (toplam $1500 \mathrm{ml}$ ) taze donmuş plazma ile Fresenius Com. Tec marka cihaz ile plazma değişim işlemi yapıldı. Hastanın klinik bulgularında belirgin bir iyileşme gözlenmesine karşın Glaskow koma skorunun halen 8-9, serum aminotriptilin seviyesinin ölümcül sınırların üstünde olması nedeniyle hastaya ikinci kez plazmaferez işlemi yapıldı. Her iki işlem sonrasında komplikasyon gözlenmedi. İkinci plazma değişiminin bitiminden yaklaşık sekiz saat sonra hastanın bilinci açıldı ve 48 saat gözlemden sonra klinik ve laboratuvar bulguları düzeldi.

\section{Tartışma}

Amitriptilin çocuklarda depresyon, enürezis nokturna, dikkat eksikliği ve hiperaktivite sendromu ve migren gibi durumlarda kullanılmaktadır. Ülkemizde ilaç kutularının çocuklar tarafından kolayca açılabilir olması zehirlenme sıklığını arttırmaktadır (4-7). Amitriptilin, etkisini adrenerjik ve seratonerjik nöronlardan epinefrin ve seratoninin geri alımını membran pompa inhibisyonu ile engelleyerek göstermektedir. Zehirlenmelerinde en sık merkezi sinir sistemi ve kardiyovasküler sistem etkilenmektedir $(8,9)$. Amitriptilin zehirlenmelerinde tanı koymada ilacın kan düzeyine bakmak en çok kullanılan yöntemdir. Çocukluk çağında kesin bir doz sınırı yoktur. Öldürücü doz genellikle 15-30 mg/kg'ın üzerinde kabul edilmektedir. İlacın antidotu olmadığından her iki hastamızda da semptomatik tedavi uygulandı. Yeterli yanıt alınamadığından plazmaferezden faydalanabileceği düşünüldü.

Plazmaferez, birçok immünolojik ve toksik hastalıkta kullanılan özgün olmayan bir tedavi yöntemidir. Belirli ve geleneksel tedavilere yanit vermeyen hastalarda plazmaferez tedavisi ile düzelme olmaktadır (2-4). Yurt içindeki ve yurt dışındaki yayınlarda, çocukluk çağındaki hayatı tehdit eden trisiklik (amiltiriptilin) antidepresan zehirlenmelerinde plazmaferez işleminin etkili olduğu bildirilmektedir (2-4, 8-10). Başvuru anında Glaskow koma skoru 4 olan hastalarımızın plazmaferezden sonra bilinci açıldı. Başvurularının 48. saatinde genel durumları ve yaşamsal bulguları tamamen düzelmiş halde taburcu edildi.

Bu yazı ile çocukluk çağının ağır amtriptilin zehirlenmelerinde plazmaferez tedavisinin hayat kurtarıcı olabileceğinin akılda tutulması gerektiğini vurgulamak istedik.

\section{Kaynaklar}

1. Rodgers GC, Condurache T, Reed MD, Bestic M. Poisonings In: Behrman RE, Kliegman RM, Jenson HB, (eds). 18 th ed. Nelson textbook of pediatrics. Philadelphia: Saunders 2007: 339-57.

2. Nenov VD, Marinov P, Sabeva J, Nenov DS. Current applications of plasmapheresis in clinical toxicology. Nephrol Dial Transplant 2003; 18: 56-8.

3. Yıldırım C. Acil serviste plazmaferez uygulamaları. Akademik Acil Tıp Dergisi 2007; 1: 9-12.

4. Ağın H, Çalkavur Ş, Balım H, Çelik T, Bak M. Çocuklarda trisiklik antidepresan intoksikasyonu. Çocuk Dergisi 2004; 4: 46- 50.

5. Öner N, Vatansever Ü, Turan Okutan Ö, ve ark. Çocuklarda sık görülen zehirlenmelerden biri: amitriptilin zehirlenmesi. T Klin J Pediatr 2004; 13: 123-8.

6. Yılmaz HL, Özcan K, Yıldızdaş D, İncecik F, Erbey F Günümüzde en sık karşılaşılan zehirlenme etkeni: amitriptilin. 39. Türk Pediatri kongresi, 17-22 Haziran 2003. Kongre kitapçığı, 450.

7. Daly JM, Wilens T. The use of tricyclic antidepressants in children and adolescents. Pediatr Clin North Am 1998; 45: 1123-35.

8. Cimili C. Sık görülen aşırı doz alımları: antidepresan ilaçlarla zehirlenmeler. T Klin Farmakoloji 2003; 1: 82-7.

9. Belen B, Akman A, Yüksel N, Dilsiz G, Yenicesu I, Olguntürk R. Case report of amitriptyline poisoning successfully treated with the application of plasma exchange. Ther Apher Dial 2009; 13: 147-9.

10. Kolsal E, Tekin IO, Piskin E, et al. Treatment of severe amitriptyline intoxication with plasmapheresis. J Clin Apher 2009; 24: $21-4$. 